\title{
Autonomija međunarodnih podružnica u inovativnoj farmaceutskoj industriji u Republici Hrvatskoj
}

\section{The autonomy of international subsidiaries in innovative pharmaceutical industry in the Republic of Croatia}

\section{Sažetak}

U radu je istražen odnos međunarodnih podružnica inovativne farmaceutske industrije u Republici Hrvatskoj i njihovih matičnih poduzeća. Cilj je bio utvrditi autonomiju međunarodnih podružnica i identificirati njihovo samoinicijativno djelovanje na lokalnoj i međunarodnoj razini. U istraživanju je sudjelovalo 17 međunarodnih podružnica inovativne farmaceutske industrije u Republici Hrvatskoj od ukupno 23 međunarodne podružnice inovativne farmaceutske industrije. Rezultati su pokazali značajnu ovisnost poslovanja međunarodnih podružnica o strategijama matičnog poduzeća te njihovu visoku prilagodbu lokalnom tržištu. Međunarodne podružnice pokazale su afinitet za provođenje vlastitih inicijativa, koje ovise o podršci matičnih poduzeća. Odnosi s matičnim poduzećem variraju među podružnicama, no može se zaključiti kako je stupanj autonomije međunarodnih podružnica u Republici Hrvatskoj ograničen.

Ključne riječi: međunarodne podružnice, matična poduzeća, inovativna farmaceutska industrija, autonomija, multinacionalne korporacije

JEL klasifikacija: F23, M16

\section{Abstract}

The paper represents a research on the relationship between international subsidiaries in the Innovative Pharmaceutical Industry and their parent companies. The aim was to determine the autonomy of international subsidiaries and to identify their self-initiative activities on both local and global level. The research included 17 international subsidiaries in the Innovative Pharmaceutical Industry in the Republic of Croatia of overall 23 international subsidiaries in the Innovative Pharmaceutical Industry. The results showed a significant dependence of management of international subsidiaries on strategies of a parent company and also their high adaptation to the local market. International subsidiaries showed the affinity to conduct their own initiatives, which depend on the support of the parent companies. The relationships with parent company vary from one international subsidiary to another, but it can be concluded that there is a limited level of autonomy of the international subsidiaries in the Republic of Croatia.

Keywords: international subsidiaries, parent companies, innovative pharmaceutical industry, autonomy, multinational corporations

JEL classification: F23, M16 
Podrug, N., Filipović, D., Bošnjak, M.

Autonomija međunarodnih podružnica u inovativno farmaceutskoj industriji u Republici Hrvatskoj

\section{Uvod}

Globalizacija i internacionalizacija poslovanja doveli su do razvoja međunarodnih poduzeća i njihove snažne prisutnosti na inozemnim tržištima kroz osnivanje međunarodnih podružnica. Međunarodne podružnice danas poduzimaju inicijative i preuzimaju aktivnosti koje su vezane uz razne oblike podrške matičnom poduzeću. Inovativna farmaceutska industrija jedna je od globalno vodećih, dok je, s obzirom na svoju specifičnost, vrlo složena i regulirana,te se postavlja pitanje u kojem opsegu njezine međunarodne podružnice mogu djelovati samostalno i proaktivno. Predmet istraživanja rada jest prikazati ulogu međunarodnih podružnica kao bitnog segmenta u globalnom lancu opskrbe lijekova te važnost njihove autonomije i inicijativa za dobrobit poslovanja matičnog poduzeća. Cilj rada je utvrditi mogućnost samostalnog i proaktivnog djelovanja, ispitati stavove 0 autonomiji međunarodnih podružnica u inovativnoj farmaceutskoj industriji u Republici Hrvatskoj i njihovom odnosu s matičnim poduzećima. Međunarodne podružnice okupljene su u udruzi Inovativna farmaceutska inicijativa, te su se na nacionalnoj razini ispitali stavovi njezinih članica. Rad je, uz uvod i zaključak, podijeljen u tri glavna poglavlja. U drugom poglavlju rada dan je pregled literature $s$ dosadašnjim ključnim spoznajama 0 autonomiji međunarodnih podružnica i njihovu odnosu s međunarodnim poduzećima. Definiraju se pojmovi međunarodnog poduzeća i međunarodne podružnice. Potom se objašnjava uloga međunarodnih podružnica, njihova mogućnost provođenja inicijativa, te pojašnjava djelovanje inovativne farmaceutske industrije u Republici Hrvatskoj. U trećem poglavlju objašnjena je metodologija vezana uz provođenje empirijskog istraživanja, te se potom iznose empirijski podaci.U empirijskom dijelu analiziraju se odgovori dobiveni od članica Inovativne farmaceutske inicijative o njihovu odnosu s matičnim poduzećima. Nastojalo se utvrditi stav podružnica o zavisnosti o njemu, mogućnosti inovativnog i proaktivnog djelovanja podružnice te ocijeniti vlastiti stupanj autonomije u odnosu na matično poduzeće. U završnom dijelu slijede zaključna razmatranja uključujući ograničenja i preporuke za buduća istraživanja.

\section{Pregled literature}

\subsection{Pojmovno određenje međunarodnog poduzeća i međunarodnih podružnica}

Za poduzeća koja sudjeluju na inozemnom tržištu koriste se različiti termini. Nazivaju se međunarodnim poduzećima, globalnim korporacijama, multinacionalnim ili transnacionalnim korporacijama odnosno konglomeratima. Međunarodna poduzeća su kompleksni, višeznačni entiteti, koji mogu biti promatrani kroz velik broj konceptualnih pogleda. Imaju formalne strukture i kontrolne sustave, mogu biti modulirani kao mreže, središta su političkih interesa i centara moći, te kroz svoje poslovanje razvijaju svijest 0 kulturološkim različitostima (Birkinshaw, 2014.). Adler razlikuje domaća i međunarodna poduzeća prema dva ključna čimbenika, multikulturalnosti i geografskoj raspršenosti, pri čemu multikulturalnost označava prisutnost zaposlenika iz dvije ili više različitih kultura, a geografska raspršenost prisutnost jedinica matične organizacije u različitim zemljama (Harzing i Van Ruysseveldt, 2004.). Navaretti i Venables (2006.) ističu kako su međunarodna poduzeća ona koja posjeduju značajan udio vlasništva, obično $50 \%$ ili više, drugog poduzeća koje posluje u drugoj državi. Dunning multinacionalne korporacije definira kao korporacije koje su uključene u izravna inozemna ulaganja te provode i kontroliraju aktivnosti koje stvaraju dodanu vrijednost u drugim državama (Rahimić i Podrug, 2013.). Prema Rakiti (2006.), multinacionalne korporacije su one koje razmišljaju i djeluju koristeći se međunarodnom i nadnacionalnom logikom pri razvoju tržišta, proizvodnje i tehnologije, a u isto vrijeme mogu aktivno i direktno utjecati na konkurentske odnose na međunarodnoj i svjetskoj razini. Wilkins (1970.) smatra kako su najvažniji faktori stvaranja multinacionalnih korporacija: koncentracija i centralizacija kapitala, povećano sudjelovanje u tehničkim i tehnološkim faktorima, te znanstveni i tehnološki razvoj.Zatim su to tehnička unaprjeđenja u komunikaciji, komunikacijskoj i informacijskoj tehnologiji te nejednaka raspodjela ekonomskog razvoja i proizvodne moći u svijetu (Loku i Shehu Loku, 2016.). 
Važnost međunarodnih poduzeća, odnosno multinacionalnih korporacija je neosporna. One utječu na alokaciju i korištenje resursa, stvaranje novih proizvoda i usluga, razvoj novih načina proizvodnje i distribucije. Dok su Ujedinjeni narodi početkom 1970-ih godina međunarodno poduzeće definirali kao poduzeće koje kontrolira imovinu, tvornice, rudnike, prodajne urede u dvije ili više zemalja, desetak godina nakon, sve se više počinje rabiti naziv transnacionalna korporacija. Transnacionalne korporacije definiraju se kao poduzeća koja imaju poslovne entitete u dvije ili više zemalja, nevezano uz pravnu formu i područje aktivnosti tih entiteta. Imaju sustav odlučivanja koji omogućuje koherentne politike i zajedničke strategije koordinirane iz jednog ili više centara odlučivanja. Entiteti su povezani tako da jedan ili više njih može utjecati na aktivnosti drugih, posebice prilikom dijeljenja znanja, resursa i odgovornosti. Strukturno definiranje multinacionalnih korporacija obuhvaća nekoliko kriterija za definiranje međunarodnih poduzeća, poput broja zemalja, vlasništva i organizacijske strukture. Prema širem strukturnom pristupu, multinacionalne korporacije imaju vlastite diverzificirane poslovne aktivnosti $u$ više od jedne zemlje, dok njihovo vlasništvo može biti samostalno ili mješovito. Njihove poslovne aktivnosti mogu se realizirati i putem partnerskih odnosa kroz licencu ili samostalnu podružnicu. Prema restriktivnom pristupu, multinacionalne korporacije su nadnacionalne organizacije s većim brojem vlastitih podružnica (Rahimić i Podrug, 2013.).

U kontekstu širenja poduzeća na inozemna tržišta, važno je definirati pojam međunarodne podružnice kao jedan način izlaska na inozemna tržišta (Kutschker i Schmid, 2011.). Prema Birkinshawu i suradnicima (2005.), podružnica je operativna jedinica koja je pod kontrolom međunarodnog poduzeća, a locirana je izvan nacionalnih granica.

Matić (2016.) razlikuje vlastitu poslovnicu i vlastito poduzeće u inozemstvu. Navodi kako je vlastita poslovnica $u$ inozemstvu inačica poslovnice $u$ zemlji, dok se vlastito poduzeće u inozemstvu bavi poslovima prodaje, distribucije i promocije na određenom inozemnom tržištu, plasirajući pri tome proizvode matičnog poduzeća prije svega veletrgovcima, dilerima i, u određenim slučajevima, velikim industrijskim potrošačima. Uz to što su vlastite tvrtke izravna veza sa stranim tržištem, one mogu, ovisno o vrsti robe, organizirati skladišta, obavljati servis i slično. S gledišta matičnog poduzeća u zemlji, poslovanje s vlastitim poduzećem $u$ inozemstvu slično je poslovanju sa stranim distributerom, osim što menadžer tog poduzeća odgovara izravno njemu i ima ulogu namještenika.

Koncept međunarodnih podružnica odnosi se na polu-autonoman entitet koji djeluje u izrazito kompleksnom okruženju i ima određeni stupanj autonomije u poslovanju (Rahimić i Podrug, 2013.). Kompleksno okruženje obilježavaju interni faktori poput drugih međunarodnih podružnica, internih kupaca i dobavljača, te eksterni faktori poput ostalih kupaca, dobavljača i konkurenata (Birkinshaw i suradnici, 2005.). Međunarodne podružnice ne moraju biti u potpunom vlasništvu multinacionalne korporacije, te je u novije vrijeme sve veći udio zajedničkih ulaganja i kooperativnih aranžmana (Rahimić, Podrug, 2013.). Prilikom osnivanja međunarodnih podružnica potrebno je ulaganje velikih resursa te je to najveći nedostatak ovakvog širenja na inozemno tržište. Ono se može odvijati kroz kupnju postojećeg poduzeća ili osnivanje novog (Matić, 2016.). Kupnjom postojećeg poduzeća na inozemnom tržištu, osnivač preuzima proizvodnu liniju, odnosno proširuje proizvodni asortiman i dobiva distributivnu mrežu, te mora dodatno educirati zaposlenike i prilagoditi mrežu asortimanu kojeg posjeduje. Osnivanjem novog poduzeća, osnivač ima potpunu kontrolu nad cjelokupnim poslovanjem i donosi dugoročne strategije koje će implementirati na međunarodnom tržištu (Malenica i Dobrić, 2014.).

Trenutak za otvaranje međunarodne podružnice nastupa onda kada dosegnuti promet i ostvarena dobit opravdavaju troškove njezinoga osnivanja i djelovanja, te kada uz to postoje i jasni izgledi za rast prometa i dobiti u budućnosti. Propisi i državna politika određene strane zemlje važan su čimbenik za donošenje odluke o osnivanju međunarodne podružnice u toj zemlji, a važni su i za uspješno poslovanje poduzeća.Značajni su i porezni i devizni propisi, posebice odredbe 0 transferu profita $u$ inozemstvo i propisi o zapošljavanju na ciljanom
Podrug, N., Filipović, D., Bošnjak, $M$.

Autonomija međunarodnih podružnica u inovativnoj farmaceutskoj industriji u Republici Hrvatskoj 
Podrug, N., Filipović, D., Bošnjak, M.

Autonomija međunarodnih podružnica u inovativno farmaceutskoj industriji u Republici Hrvatskoj inozemnom tržištu, jer će matično poduzeće nastojati zaposliti osobe koje su dotad radile $u$ zemlji i nacionalnosti su zemlje u kojoj se nalazi međunarodna podružnica (Matić, 2016.).Definiranje koncepta međunarodnih podružnica seže u 1950tu godinu te se on s vremenom mijenjao, ovisno o tome kako su se mijenjali pogledi autora na međunarodno poduzeće. Nakon konceptualizacije, autori su se okrenuli definiranju uloga međunarodnih podružnica u ovisnosti o različitim dimenzijama, odnosu s matičnim poduzećima te razvoju međunarodnih podružnica (Kovač, 2017.).

\subsection{Autonomija međunarodnih podružnica u odnosu na matična poduzeća}

Međunarodne podružnice imaju veliku važnost jer međunarodnom poduzeću daju komparativnu prednost u odnosu na ostala poduzeća, te posljednjih godina njihove aktivnosti imaju sve značajniju ulogu. Međunarodnim podružnicama i divizijskom menadžmentu dana je sve veća autonomija, s manjom koordinacijskom funkcijom od strane korporativnog menadžmenta (Leksell, 1981.). Prvu studiju vezanu uz autonomiju međunarodnih podružnica objavljuje Skinner 1968. godine. Pojam autonomije u menadžmentu međunarodnih podružnica iz različitih perspektiva potom objašnjava velik broj autora (Johnston, 2005.).

Chiao i Ying (2013.) razmatraju autonomiju međunarodnih podružnica u širokom kontekstu, dok ju pojedini autori vežu uz određena obilježja, poput veličine međunarodnih podružnica (Johnson i Menguc, 2007.), udaljenosti od matičnog poduzeća (Jong i suradnici, 2015.), starosti (Raziq i suradnici, 2014.), kulturalnih razlika (Puck i suradnici, 2016.), stila menadžmenta (Jakobsen i Rusten, 2003.) ili uspješnosti poslovanja (Gammelgaard i suradnici, 2012.). Zahra (1991.) tvrdi kako je autonomija usko vezana uz poduzimanje strateških inicijativa međunarodnih podružnica. Brooke (1984.) pod autonomijom u odlučivanju podrazumijeva organizaciju u kojoj njezine jedinice posjeduju mogućnost donošenja samostalnih odluka oko pitanja koja uključuju i višu organizacijsku razinu. Roth i Morrison (1992.) autonomiju definiraju slično, kao stupanj u kojem međunarodna podružnica odluke može donositi samostalno, dok ju Bartlett i Ghoshal (1988.) vežu uz vlastiti inovativni potencijal.

Tradicionalno su studije ovog odnosa imale hijerarhijsku perspektivu, prema kojoj su matična poduzeća kontrolirala međunarodne podružnice i donosila strateške odluke (Dicken, 1976.). Prve međunarodne podružnice bile su minijaturne replike, gotovo bez odgovornosti i mogućnosti utjecaja na poslovanje. Globalizacija i liberalizacija utjecali su na to da one preuzmu veće uloge u modificiranju poslovanja. S vremenom su međunarodne podružnice razvile i vlastite resurse, te matična poduzeća više nisu isključivi izvor konkurentne prednosti. Razvijaju se nova razmatranja, poput heterarhijskog i transnacionalnog (Kovač, 2017.). Ranija istraživanja odnosa matičnog poduzeća i međunarodne podružnice isticala su sposobnost podružnice za samostalno donošenje odluka, te se pokazalo kako se ona znatno razlikuje između pojedinih matičnih poduzeća, kao i između pojedinih međunarodnih podružnica (Picard, 1980.). Prema Ambosu i suradnicima (2011.), koncept autonomije odnosi se na to kako će veći rast međunarodnih podružnica biti moguć samo uz manju ovisnost o drugima i manje slijeđenja uputa međunarodnog poduzeća. Ambos i Birkinshaw (2010.) autonomiju međunarodnih podružnica promatraju kroz više čimbenika: strateške uloge međunarodne podružnice, njezinog znanja i kompetencija, veličine i performansi.

Cavanagh i suradnici (2017.) razmatraju način na koji međunarodna podružnica može ostvariti određen stupanj autonomije i na koji način ju definira. Postavljaju hipotezu kako podružnica može pretpostaviti kako posjeduje određenu autonomiju, no kako ona ne mora uvijek biti i formalno priznata od strane matičnog poduzeća. Stoga, međunarodna podružnica mora posjedovati legitimnost, odnosno njezino ponašanje mora biti i prihvaćeno od strane matičnog poduzeća (Gammelgaard, 2009.). S druge strane, međunarodna podružnica može inzistirati na ostvarenju većeg stupnja autonomije, dok istovremeno matično poduzeće inzistira na većoj kontroli, ili pak međunarodna podružnica može smatrati kako vrijedi uložiti napor u određenu inicijativu, dok matično poduzeće to može smatrati oportunističkim ponašanjem u kojem međunarodna podružnica djeluje u interesu lokalnog tržišta, te je manje usredotočena na globalnu profitabilnost međunarodnog poduzeća (Ambos i Birkinshaw, 
2010.).

Forsgren i Pahlberg (1992.) u odnosu međunarodne podružnice $s$ matičnim poduzećem i načinu ostvarenja njezine autonomije razmatraju pojam moći koju ona ima unutar međunarodne korporacije. Smatraju kako se moć međunarodnih podružnica unutar korporativnog sustava temelji na strukturalnoj ili sustavnoj te resursnoj moći. Strukturalnu moć opisuju Astley i Zajac (1991.), a definiraju ju kao moć vezanu uz razinu uključenosti međunarodne podružnice u funkcionalnu zavisnost između pojedinih jedinica unutar poduzeća. Ona podrazumijeva indirektne odnose unutar šireg sustava međusobno ovisne poslovne mreže. Strukturalna moć kroz položaj u mreži najjednostavnije se objašnjava kroz centraliziranost i decentraliziranost u intraorganizacijskoj teoriji. Što je podružnica umreženija unutar sustava, to više može utjecati na strateško ponašanje cijelog međunarodnog poduzeća. Za razliku od strukturalne moći, resursna moć podrazumijeva resursnu neovisnost jedinice u odnosu na ostale jedinice unutar organizacije, te ona više može utjecati na poduzeće nego obrnuto. Što je veća mogućnost poslovanja bez ostatka međunarodnog poduzeća, to su veće neovisnost i autonomija.

Kawai i Strange (2005.) tvrde kako visok stupanj autonomije podružnice i manja interna koordinacija dovode do boljih performansa, uz određene interne i eksterne uvjete. Jednom od ključnih uloga u menadžmentu međunarodne podružnice prikazuju ulogu ekspatrijata kao glavnih moderatora odnosa međunarodne podružnice i matičnog poduzeća. Praksa raspoređivanja ekspatrijata u različite jedinice omogućava veću koordinaciju unutar međunarodnog poduzeća i manje agencijske troškove nastale zbog veće autonomije međunarodne podružnice. Autonomno ponašanje podružnice uvelike je ovisno o čimbenicima okoline i lokacijskim faktorima. Autonomija se pokazala poželjnijom na nepredvidljivim tržištima, naročito onima s naglim promjenama u tehnologiji. Uz veću autonomiju, međunarodna podružnica ne mora čekati na odobravanje matičnog poduzeća za provođenje lokalnih aktivnosti, a što joj daje prednost u odnosu na ostala inozemna poduzeća prisutna na lokalnom tržištu (Raziq i suradnici, 2014.). Leksell (1981.) navodi kako je autonomija manje izražena kod onih podružnica čija poduzeća imaju veće međunarodno iskustvo. Rastom iskustva na inozemnim tržištima, poduzeće o njima posjeduje više znanja, ali i više saznanja vezanih uz dizajn organizacije, instrumente koordinacije i kontrole nad svojim podružnicama. Međunarodne korporacije s vremenom razvijaju standardizaciju kontrolnih instrumenata kojom pristupaju svojim jedinicama. Krupka i suradnici (2008.) neovisnost podružnica stavljaju u kontekst vlasništva. Pretpostavljaju kako je autonomija podružnica veća u grupama poduzeća u kojima je vlasnička funkcija odvojena od upravljačke, nego u podružnicama grupa poduzeća u kojima su vlasnička i upravljačka funkcija objedinjene. Smatraju također kako veći stupanj autonomije podružnica pozitivno utječe na njihovu razmjenu s nepovezanim poduzećima.

Visok stupanj autonomije može biti otežavajuća okolnost, te može dovesti do nedostatka povezanosti, međusobnog učenja i dijeljenja znanja (Birkinshaw i suradnici, 2002.). S druge strane, autonomija podružnicama daje mogućnost proaktivnog djelovanja i doprinosa matičnom poduzeću. Prema Schmidu i suradnicima (2014.), stupanj autonomije međunarodnih podružnica jedan je od pokretača inicijativa međunarodnih podružnica. Strateške inicijative međunarodnih podružnica odnose se na strateške aktivnosti menadžera međunarodnih podružnica koje mogu imati značajan utjecaj na kompletno međunarodno poduzeće (Kovač, 2017.).

\subsection{Karakteristike međunarodnih podruž- nica inovativne farmaceutske industrije u Republici Hrvatskoj}

Inovativna farmaceutska industrija u Republici Hrvatskoj aktivno djeluje putem Inovativne farmaceutske inicijative. Inovativna farmaceutska inicijativa (iF!), ranije poznata kao Croatian Association of Research-based Pharmaceutical Companies (CARPC) osnovana je 1994. kao nevladina, neprofitna, nepolitička i neovisna udruga koja okuplja inovativne proizvođače lijekova prisutne na hrvatskom tržištu. U udrugu su uključena 23 inovativna farmaceutska poduzeća koja zapošljavaju ukupno 832 djelatnika te osiguravaju 60\% lijekova u Republici Hrvatskoj (Tablica 1.). Udruga je predstavničko tijelo
Podrug, N., Filipović, D., Bošnjak, M.

Autonomija međunarodnih podružnica u inovativnoj farmaceutskoj industriji u Republici Hrvatskoj 
Podrug, N., Filipović, D., Bošnjak, M.

Autonomija međunarodnih podružnica u inovativno farmaceutskoj industriji u Republici Hrvatskoj

Tablica 1. Članice Inovativne farmaceutske inicijative, međunarodne podružnice inovativnih farmaceutskih multinacionalnih korporacija u Republici Hrvatskoj

\begin{tabular}{|c|c|c|}
\hline AbbVie d.o.o. & GE Healthcare d.o.o. & Novo Nordisk Hrvatska d.o.o. \\
\hline Amgen d.o.o. & GlaxoSmithKline d.o.o. & Pfizer Croatia d.o.o. \\
\hline Astellas d.0.0. & Janssen d.o.o. & Roche d.o.o. \\
\hline AstraZeneca d.0.0. & Lundbeck Croatia d.0.o. & Sanofi-Aventis Croatia d.o.o. \\
\hline Bayer d.o.o. & Medis Adria d.o.o. & Servier Pharma d.o.o. \\
\hline Berlin-Chemie Menarini Hrvatska d.o.o. & Merck d.o.o. & Shire d.o.o. \\
\hline Boehringer Ingelheim Zagreb d.o.o. & Merck Sharp \& Dohme d.o.o. & Takeda Pharmaceuticals Croatia d.o.o. \\
\hline Eli Lilly and Company S.E. d.o.o. & Novartis Hrvatska d.o.o. & \\
\hline
\end{tabular}

Izvor: Inovativna farmaceutska inicijativa (2018.).

istraživački usmjerenih proizvođača lijekova koji su organizirani i posluju u Republici Hrvatskoj u skladu s važećim propisima (Inovativna farmaceutska inicijativa, 2018.).

Inovativna farmaceutska inicijativa pridružena je članica Europskog udruženja farmaceutskih kompanija sa sjedištem u Bruxellesu (The European Federation of Pharmaceutical Industries and Associations, EFPIA), jednog od vodećih predstavničkih tijela istraživački orijentirane farmaceutske industrije u Europi (Pogorilić, 2015.).

Nastanak prvih podružnica u inovativnoj farmaceutskoj industriji veže se uz pojavu prvih predstavništava u Republici Hrvatskoj, pa tako 1991. godine, među ukupno 32 inozemna poduzeća, Registar predstavništava stranih osoba u Republici Hrvatskoj bilježi osnivanje predstavništva danskog poduzeća Novo Nordisk te švicarskog Hoffmann-La Roche (Roche). Godine 1992. proširenom popisu s gotovo 500 novih poduzeća pridružuju se Bayer AG, Novartis, Zeneca International Limited (AstraZeneca), GlaxoSmithKline Export LTD (GlaxoSmithKline), Johnson\&Johnson (Janssen), Boehringer Ingelheim Pharma GmbH, Schering AG (Bayer) i Ciba-Geigy Services LTD (Novartis), Abbott (Abbvie) (Registar predstavništava stranih osoba u Republici Hrvatskoj, 2018.). U narednim godinama poduzeća nastavljaju osnivati svoje podružnice u Republici Hrvatskoj, od kojih je posljednja Amgen d.0.0., osnovana 2013. godine (Inovativna farmaceutska inicijativa, 2018.). Ulaskom u Europsku uniju poslovni subjekti iz država članica nisu više u mogućnosti otvoriti predstavništvo u Republici Hrvatskoj, odnosno po sili zakona postojeća strana predstavništva iz država članica Europske unije prestala su postojati. Poslovni subjekti iz država članica mogu se registrirati isključivo kao podružnica ili trgovačko društvo. Po odredbama Zakona o trgovačkim društvima (Narodne novine, 111/93, 111/12), inozemna trgovačka društva i inozemni trgovci pojedinci ne mogu trajno obavljati djelatnost na području Republike Hrvatske dok ne osnuju podružnicu. Djelovanjem podružnice, prava i obveze preuzima osnivač, mora navesti svoje sjedište i sjedište osnivača i voditi poslovne knjige po propisima koji se primjenjuju u Republici Hrvatskoj (Lukač, 2013.).

Matična poduzeća međunarodnih podružnica inovativne farmaceutske industrije u Republici Hrvatskoj u najvećem su broju iz SAD-a $(6$ međunarodnih podružnica), Njemačke (4 međunarodne podružnice), dok in slijede ostale europske zemlje, i to najviše Danska, Francuska, Švicarska i Ujedinjeno Kraljevstvo s 2 međunarodne podružnice u Republici Hrvatskoj, te Japan s također 2 međunarodne podružnice.

\section{Metodologija}

Istraživački dio rada odnosio se na ispitivanje podružnica inovativne farmaceutske industrije u Republici Hrvatskoj o njihovom odnosu s matičnim poduzećem, a u svrhu utvrđivanja autonomije, te mogućnosti vlastitog proaktivnog djelovanja. Upitnik se sastojao od četiri dijela, odnosno grupa pitanja u kojima je naglasak bio na stavovima podružnica o pojedinim stavkama odnosa: opće informacije o poduzeću, zavisnost podružnice o matičnom poduzeću, mogućnost inovacija i proaktivnog djelovanja podružnice te stupanj autonomije u odnosu na matično poduzeće.

Upitnik je sadržavao ukupno 35 pitanja. Prvi dio upitnika se odnosio na opće podatke o poduzeću kako bi se utvrdio uzorak prikupljenih poduzeća s obzirom na lokaciju njihovog matičnog poduzeća 
te vremenske prisutnosti u Republici Hrvatskoj. Druga tematska grupa uključuje ukupno šest pitanja. Međunarodne podružnice u svom djelovanju često su ovisne o poslovanju i aktivnostima svojih matičnih poduzeća. Tako, dok s jedne strane postaju polu-autonoman entitet koji djeluje u kompleksnoj okolini, istovremeno zadržavaju suženu razinu odgovornosti. U ovom dijelu se nastojalo utvrditi stav podružnice o vlastitoj zavisnosti o matičnom poduzeću.

Poznato je kako međunarodne podružnice poznaju lokalno tržište u većoj mjeri nego što su saznanja koja posjeduje matično poduzeće. S obzirom na djelovanje podružnica na lokalnoj razini, podružnicama se omogućava pokretanje vlastitih inicijativa i proaktivnog djelovanja u svojoj okolini. Treća grupa pitanja odnosi se na mogućnost takvog djelovanja, odnosno mogućnost inovacija i proaktivnog djelovanja podružnica kao stavke vezane uz autonomiju u odnosu na matično poduzeće. Odnosi se na ukupno devet pitanja upućenih podružnicama inovativne farmaceutske industrije u Republici Hrvatskoj.

Četvrta grupa pitanja odnosi se na konačnu ocjenu o vlastitoj autonomiji. Stupanj u kojem međunarodna podružnica može samostalno donositi odluke može varirati od strateškog odlučivanja u podružnici do odlučivanja u matičnom poduzeću. Međunarodne podružnice suočene su $s$ internim i eksternim okruženjem u kojem djeluju, kao i internim i eksternim pritiscima u sklopu kojih trebaju ostvariti vlastitu legitimnost. Posljednja grupa od osam pitanja odnosi se na konačnu ocjenu postizanja takve legitimnosti i prihvaćanju od okoline i matičnog poduzeća.

Istraživanje je bilo odobreno od strane Inovativne farmaceutske inicijative te su upitnici proslijeđeni podružnicama s naznakom kako ispunjavanje treba biti od strane osoba koje su upućene u ovaj vid odnosa s matičnim poduzećem. Rok za ispunjavanje upitnika bio je mjesec dana.

\section{Empirijski rezultati i diskusija}

U istraživanju je sudjelovalo 17 od 23 poduzeća,što znači povrat od $74 \%$. Prema rezultatima vezanim uz dolazak inozemnih inovativnih farmaceutskih poduzeća u Republiku Hrvatsku, upitnik su u najvećem broju (76\%), ispunile podružnice koje su prisutne na nacionalnom području u razdoblju od šest do petnaest godina. Navedeno razdoblje ujedno označava vremenski period u kojem su međunarodne podružnice imale iskustvo

Slika 1.Vremenska prisutnost međunarodnih podružnica multinacionalnih korporacija inovativne farmaceutske industrije na teritoriju Republike Hrvatske

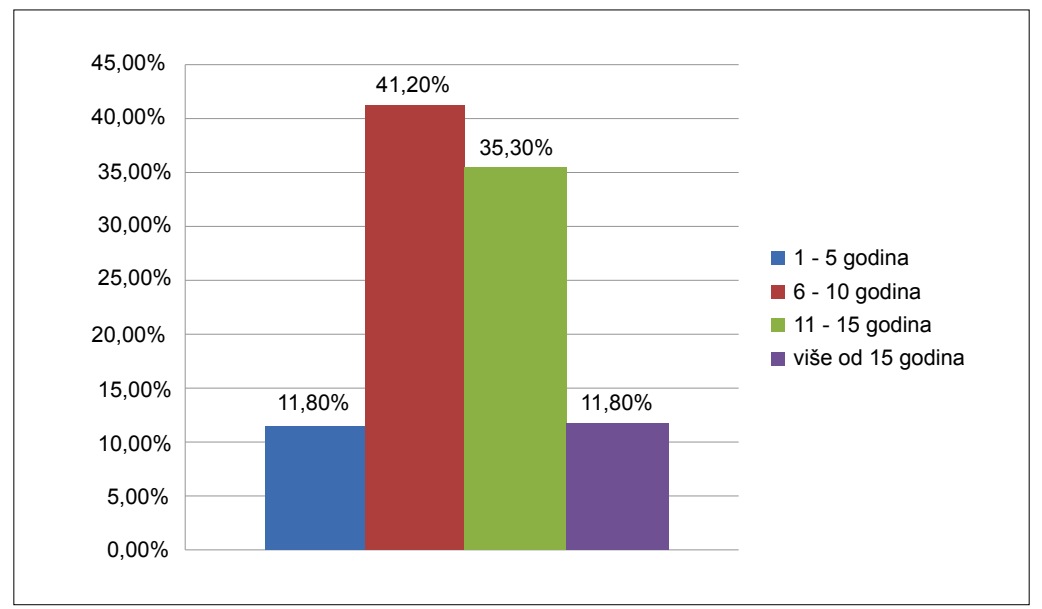

Izvor: izrada autora. 
Podrug, N., Filipović, D., Bošnjak, M.

Autonomija međunarodnih podružnica u inovativno farmaceutskoj industriji u Republici Hrvatskoj poslovanja s matičnim poduzećem, a na tržištu Republike Hrvatske (Slika 1.).

Prema dobivenim podatcima, matična poduzeća većine ispitanih međunarodnih podružnica (53\%) nalaze se izvan Europske unije, u prvom redu u Sjedinjenim Američkim Državama. U skladu s tim, najveći broj podružnica (59\%) posjeduje regionalni centar u regionalno bliskoj zemlji, a koja je u direktnom odnosu s matičnim poduzećem koje se nalazi u zemlji domaćina. Utvrđeno je kako ovakva organizacijska struktura nije praksa samo među međunarodnim korporacijama $s$ matičnim poduzećima izvan Europske unije, već i onih unutar nje. Europska poduzeća također organiziraju regionalne centre unutar svog gospodarskog prostora. U $18 \%$ slučajeva pokazalo se kako je međunarodna podružnica u Republici Hrvatskoj odgovorna za regiju, odnosno za podružnice i izvan Republike Hrvatske.

Međunarodne podružnice u Republici Hrvatskoj većinom su se izjasnile kako međunarodne korporacije, čiji su sastavni dio, broje više od 50 međunarodnih podružnica diljem svijeta. Samo jedna podružnica izjasnila se kako njezino poduzeće broji do 10 međunarodnih podružnica na globalnoj razini, dok se, uz 58,8\% najvećih, ukupno 29,5\% odnosi na podružnice koje pripadaju međunarodnim poduzećima koja broje prisutnost u 21 do 50 zemalja. Međunarodne podružnice Inovativne farmaceutske inicijative koje su sudjelovale u ispunjavanju upitnika su različite veličine kad je riječ o broju zaposlenika u Republici Hrvatskoj. Tako većina broji od 21 do 40 zaposlenika. Kada su upitane koliko među njima ima inozemnih zaposlenika u Republici Hrvatskoj, sve podružnice $(100 \%)$ su odgovorile kako se taj broj odnosi na raspon od 1 do 5 osoba. Utvrđeno je kako su to najčešće ekspatrijati različitih nacionalnosti i na vodećim pozicijama u međunarodnim podružnicama (državljanstava Belgije, Turske, Njemačke, Francuske), postavljene od strane matičnog poduzeća za vođenje poslovanja u Republici Hrvatskoj (Slika 2.).

Kako bi se utvrdila uloga međunarodne podružnice u odnosu na matično poduzeće ili regionalni centar, u oba slučaja podružnice su se identificirale kao većinski implementatori, odnosno kako provode strategiju postavljenu od strane inozemnih poduzeća. To je slučaj u $76,5 \%$ međunarodnih podružnica koje odgovaraju direktno matičnom poduzeću i $64 \%$ slučajeva koje su u direktnom odnosu s regionalnim centrom. Niti jedna podružnica u oba slučaja nije se izjasnila kao strateški vođa, odnosno kako ima stratešku važnost za poduzeće, no isto tako niti jedna podružnica nije se definirala kao crna rupa, odnosno kako nema dovoljno sposobnosti za provođenje strategije inozemnih poduzeća. U oba slučaja $23,5 \%$ podružnica su se izjasnile kao kontributori, odnosno kako posjeduju specifične sposobnosti za razvijanje poslovanja, dok se $12,5 \%$ podružnica izjasnilo kako

Slika 2. Vremenska prisutnost međunarodnih podružnica multinacionalnih korporacija inovativne farmaceutske industrije na teritoriju Republike Hrvatske

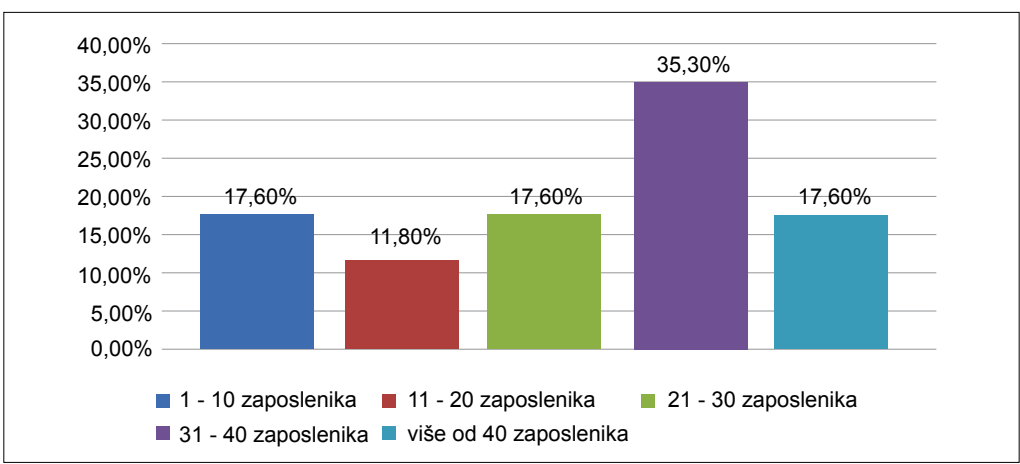

Izvor: izrada autora. 
Slika 3. Percepcija međunarodnih podružnica o odlučivanju

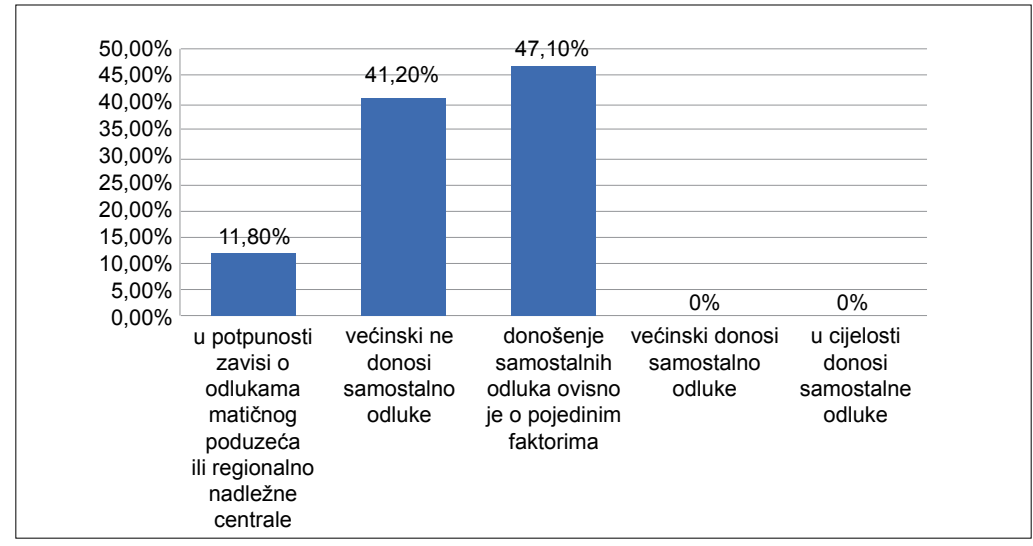

Izvor: izrada autora.

upravo one posjeduju ulogu regionalnog centra.

Međunarodne podružnice koje su sudjelovale u istraživanju ne posjeduju vlastito skladište te se skladištenje odvija putem drugih poduzeća. Najčešće su to veledrogerije u Republici Hrvatskoj koje tako onda mogu skladištiti proizvode više međunarodnih poduzeća istovremeno. Pojedina inozemna poduzeća imaju svoja skladišta ili koriste unajmljene prostore u susjednim zemljama, te za iste nemaju potrebe unutar Republike Hrvatske. Proizvodnja ovih poduzeća ne odvija se u Republici Hrvatskoj, te u tom segmentu ipak najviše prevladavaju domaće generičke tvrtke. Možda najbliži slučaj proizvodnji jednog međunarodnog inovativnog poduzeća može se povezati s poduzećem Pfizer u sklopu kojeg od 2015. posluje Hospira Zagreb d.o.0., a koja je poslovanje u Hrvatskoj započela kupnjom Plivinog biotehnološkog pogona u Savskom Marofu. Vlastitu distribuciju za bolničke potrebe ostvaruje tvrtka Roche.

Međunarodne podružnice upitane su za integriranost s matičnim poduzećem i lokalnim, odnosno nacionalnim tržištem. Većina međunarodnih podružnica odgovorila je kako je u potpunosti integrirana i vrlo integrirana s matičnim poduzećem (88,2\%), ali i lokalnim tržištem (94,2\%). S obzirom da je farmaceutska industrija snažno zakonodavno regulirana, razumljiv je visoki stupanj integriranosti s lokalnim tržištem.

Nadalje, analizirane su odluke koje donose međunarodne podružnice inovativne farmaceutske industrije u Republici Hrvatskoj. U najvećem broju slučajeva pokazalo se kako donošenje samostalnih odluka ovisi o pojedinim faktorima unutar i izvan poduzeća $(47,1 \%)$, te kako je vrlo mala razlika između njih i podružnica koje većinski ne donose samostalne odluke ili pak u potpunosti ovise o politici međunarodnih poduzeća i matičnog poduzeća (53\%). Niti jedan odgovor nije bio potvrdan kada je riječ o većinski samostalnom ili u cijelosti samostalnom donošenju odluka, što dovodi do razmatranja kako niti jedna međunarodna podružnica u inovativnoj farmaceutskoj industriji u Republici Hrvatskoj ne uživa potpunu autonomiju vlastitog djelovanja. Ovaj stav međunarodnih podružnica podupire njihovu raniju tezu i definiranje vlastite uloge implementatora na lokalnom tržištu u međunarodnom poduzeću. Pokazalo se kako, iako se javljaju prilike za mogućnost samostalnog odlučivanja i one su ovisne o situaciji, međunarodne podružnice inovativne farmaceutske industrije u Republici Hrvatskoj još uvelike ovise o strateškim i ostalim odlukama matičnih poduzeća (Slika 3.).

Također se analiziralo u kojoj mjeri međunarodne podružnice provode odluke i strategije donesene od strane matičnih poduzeća izravno ili pak neizravno putem regionalnih centara. Odgovori
Podrug, N., Filipović, D., Bošnjak, M.

Autonomija međunarodnih podružnica u inovativnoj farmaceutskoj industriji u Republici Hrvatskoj 
Podrug, N., Filipović, D. Bošnjak, M.

Autonomija međunarodnih podružnica u inovativno farmaceutskoj industriji u Republici Hrvatskoj

Slika 4. Percepcija međunarodnih podružnica o operativnom provođenju odluka

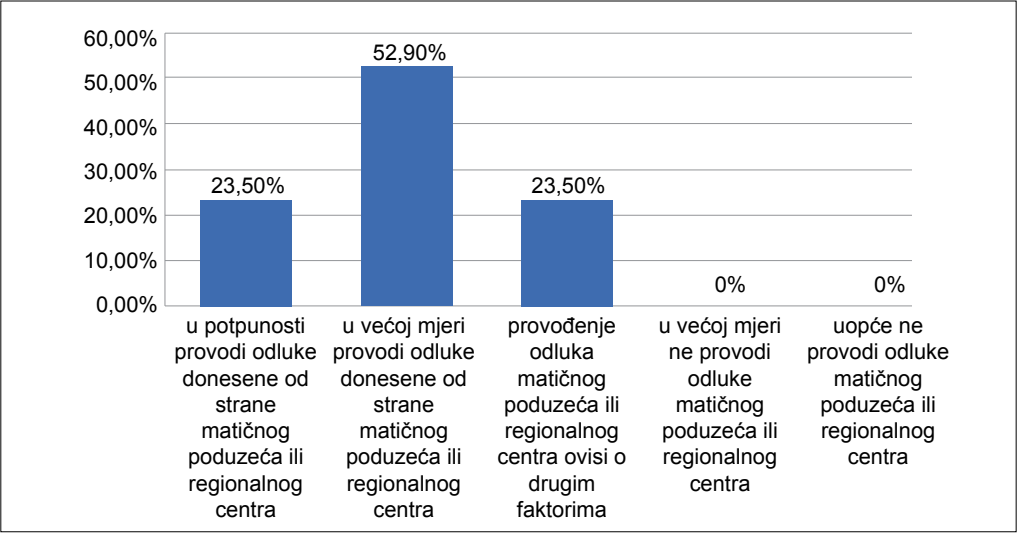

Izvor: izrada autora.

međunarodnih podružnica iz ove perspektive su slični prethodnim, no identificirana je veća razina kontrole matičnog poduzeća kad je riječ o provođenju njegovih odluka. Više od polovice analiziranih međunarodnih podružnica u većoj mjeri provodi odluke donesene od strane matičnog poduzeća ili regionalnog centra. Jednako kao i u prethodnom odgovoru, niti jedna međunarodna

Slika 5. Analiza aktivnosti koje se provode u međunarodnoj podružnici prema izvoru inicijative

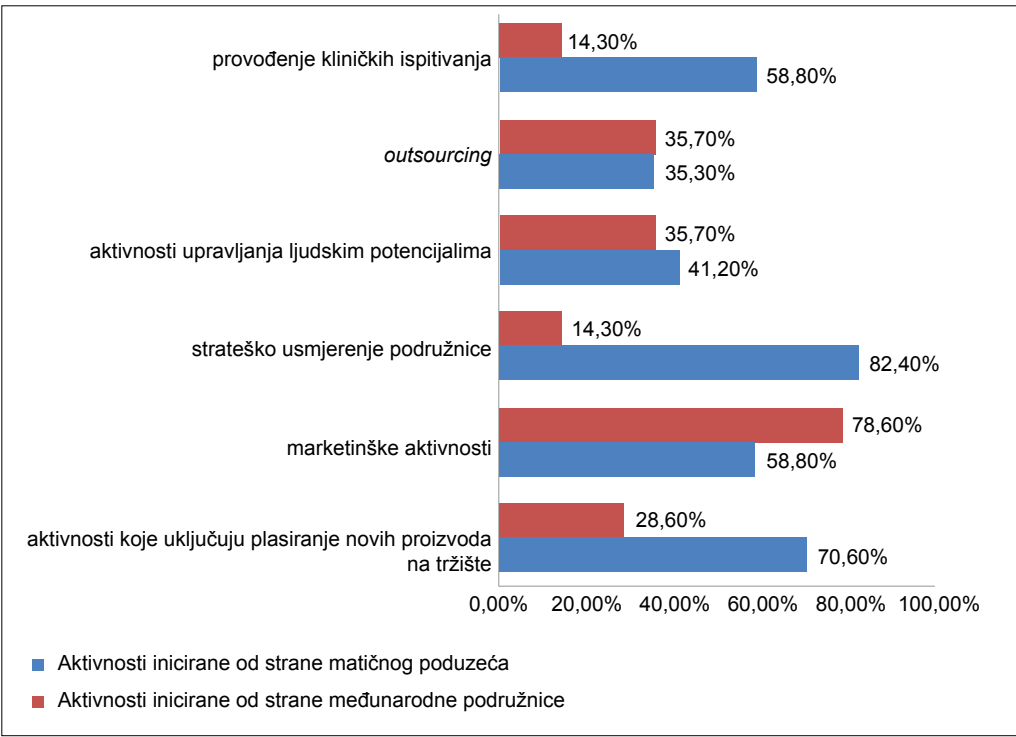

Izvor: izrada autora. 
Slika 6. Percepcija međunarodnih podružnica o vlastitim ulogama u odnosu na matično poduzeće

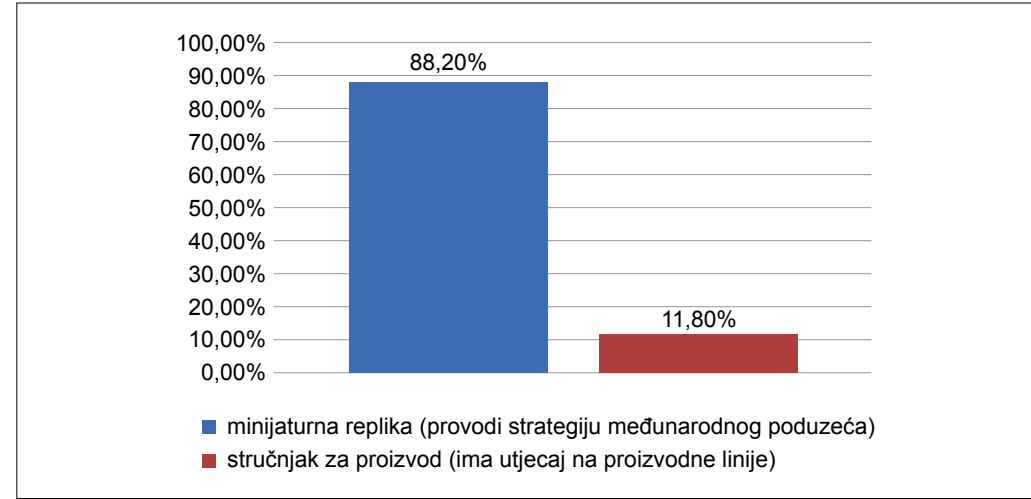

Izvor: izrada autora.

podružnica nije potvrdila kako u većoj mjeri ili uopće ne provodi odluke matičnog poduzeća ili regionalnog centra (Slika 4.).

Slika 5. prikazuje rezultate istraživanja vezane uz aktivnosti koje se provode u međunarodnoj podružnici u ovisnosti o tome jesu li inicirane od strane matičnog poduzeća ili međunarodne podružnice. $U$ najvećem postotku matično poduzeće inicira aktivnosti koje se odnose na strateško usmjerenje podružnice $(82,4 \%)$ te na aktivnosti koje uključuju plasiranje novih proizvoda na tržište $(70,6 \%)$. Pojedine podružnice naglasile su važnost kliničkih ispitivanja koja su potaknuta od strane matičnih poduzeća $(58,8 \%)$. Najmanji udio inicijativa od strane matičnog poduzeća se odnosi na aktivnosti outsourcinga što je razumljivo jer nije riječ o strateški važnim elementima poslovanja koji bi bili interesantni matičnom poduzeću.

Međunarodne podružnice iskazale su najviši stupanj samostalnosti u marketinškim aktivnostima, potom u aktivnosti upravljanja ljudskim potencijalima, te aktivnostima outsorucinga, što je u skladu s teorijskim postavkama kako su te funkcije najčešći kandidati za decentralizaciju aktivnosti unutar grupe međunarodnog poduzeća.

U sljedećem pitanju nastojala se identificirati

Slika 7. Broj inicijativa potaknutih od strane međunarodnih podružnica u inovativnoj farmaceutskoj industriji u Republici Hrvatskoj

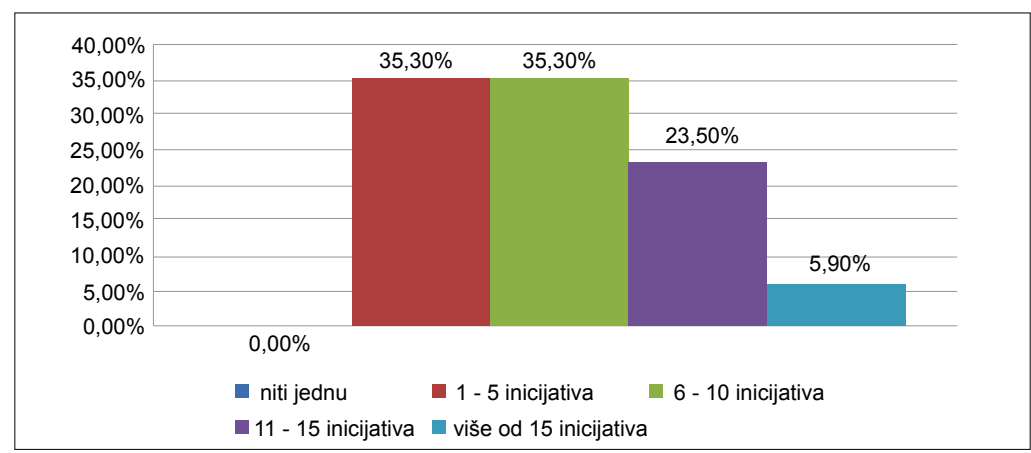

Izvor: izrada autora. 
Podrug, N., Filipović, D., Bošnjak, M.

Autonomija međunarodnih podružnica u inovativno farmaceutskoj industriji u Republici Hrvatskoj

Slika 8. Stav međunarodnih podružnica o prijenosu znanja između matičnog poduzeća i međunarodne podružnice

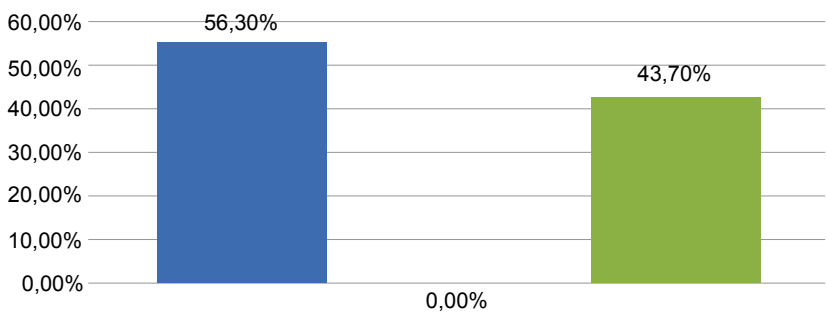

- veći je prijenos znanja iz matičnog poduzeća ili regionalno nadležne države u podružnicu

- veći je prijenos znanja iz podružnice u matično poduzeće ili reginalno nadležnu centralu

- jednak je prijenos znanja u oba smjera

Izvor: izrada autora.

Tablica 2. Odnos međunarodnih podružnica u inovativnoj farmaceutskoj industriji u Republici Hrvatskoj s matičnim poduzećem, lokalnim tržištem i regionalnim centrom

\begin{tabular}{|l|c|}
\hline Strategija poslovanja međunarodne podružnice je definirana od strane matičnog poduzeća & Ocjena \\
\hline Marketinške aktivnosti su definirane od strane matičnog poduzeća & 4,23 \\
\hline Matično poduzeće definira prioritete u proizvodnom asortimanu & 4,18 \\
\hline Matično poduzeće uvjetuje broj zaposlenika i očekivane poslovne rezultate & 4,35 \\
\hline Poslovanje podružnice je specifčno i ovisno o lokalnoj zakonskoj regulativi & 4,29 \\
\hline Ocjena cjelokupne povezanosti međunarodne podružnice s matičnim poduzećem & 4,59 \\
\hline Ocjena cjelokupne povezanosti međunarodne podružnice s regionalnim centrom & 4,47 \\
\hline Ocjena suradnje s matičnim poduzećem & 4,65 \\
\hline
\end{tabular}

Izvor: izrada autora.

uloga međunarodne podružnice u odnosu na matično poduzeće. U većini slučajeva međunarodne podružnice u Republici Hrvatskoj definirale su svoju ulogu kao ulogu minijaturne replike, odnosno kako samo provode strategiju međunarodnog poduzeća, dok se manji broj njih definirao kao stručnjak za proizvod koji ima utjecaj na proizvodne linije (Slika 6.).

U sljedećem dijelu upitnika pitanja su bila vezana uz mogućnost inovativnog i proaktivnog djelovanja međunarodne podružnice, te se prvo pitanje odnosilo na takvu praksu u posljednjih pet godina. Pokazalo se kako su međunarodne podružnice sklone inicijativama, pri čemu je $29,4 \%$ međunarodnih podružnica u posljednjih pet godina provelo više od 11 strateških inicijativa, dok je $70,6 \%$ provelo do 10 inicijativa. Kad je analiziran karakter inicijativa, $60 \%$ međunarodnih podružnica izjasnilo se kako su to većinom marketinške inicijative. Pojedine podružnice ponovno su dale važnost kliničkim ispitivanjima, te inicijativama koje su nastale kao reakcija na stanje na lokalnom tržištu. Među navedenim primjerima inicijativa, one su se ponajprije odnosile na kampanje podizanja svijesti o raznim bolestima, a među kojima su pojedine primijenjene i na regionalnoj razini (Slika 7.).

Također se analizirao prijenos znanja iz matičnog poduzeća u međunarodnu podružnicu i obrnuto. Većina podružnica smatra kako je veći prijenos znanja iz matičnog poduzeća ili regionalnog centra u podružnicu nego je to obrnuto, dok $43,7 \%$ smatra kako je prijenos znanja u oba smjera jednak (Slika 8.).

U posljednjem dijelu upitnika pokušao se donijeti zaključak o pojedinim aspektima odnosa 
međunarodne podružnice s matičnim poduzećem, lokalnim tržištem i regionalnim centrom. Korištena je Likertova skala od 1 do 5 , a prosječni rezultati su prikazani u Tablici 2.

Prema rezultatima iz Tablice 2. visoka je razina ovisnosti o matičnom poduzeću te ono ima visoku razinu kontrole nad svojim poduzećima kćerima. Većina međunarodnih podružnica u inovativnoj farmaceutskoj industriji u Republici Hrvatskoj ima regionalni centar, pa je stoga i bliža suradnja $s$ centrom nego s matičnim poduzećem. Poslovanje međunarodnih podružnica uvelike je koordinirano od strane matičnih poduzeća, iako one svakako trebaju slijediti i regulativu zemlje u kojoj se nalaze.

\section{Zaključak}

Međunarodno poslovanje poduzeća u vremenu globalizacije nužno je radi postizanja konkurentnosti i održavanja profitabilnosti poduzeća, naročito kada je riječ 0 visokotehnološkim industrijama poput farmaceutske. Međunarodne podružnice inovativne farmaceutske industrije posljednjih su godina znatno napredovale $s$ obzirom na svoje ranije uloge $u$ međunarodnim poduzećima. Temeljem potrebe sve većih ulaganja u istraživanje i razvoj, matična poduzeća svoje podružnice organiziraju tako da one nisu više odgovorne samo za prodaju i distribuciju proizvoda, već i za provođenje različitih kliničkih ispitivanja, proizvodnju lijekova i rada na inovativnim rješenjima u zemljama u kojima djeluju. Međunarodne podružnice inovativne farmaceutske industrije prisutne su u Republici Hrvatskoj od njezinih samih začetaka, najprije putem predstavništava, te potom i putem vlastitih poduzeća udruženih u Inovativnoj farmaceutskoj inicijativi. Osim razvoja poslovanja međunarodnih poduzeća kroz poslovne prilike na području Republike Hrvatske, dolazak i utjecaj ovih poduzeća značajan je za živote hrvatskih pacijenata, kao i za edukaciju medicinskog osoblja, koje je tako dobilo direktna znanja o novim lijekovima i metodama liječenja te priliku steći direktnu vezu s poduzećima u inozemstvu i najnovijim otkrićima. Istraživanje provedeno na međunarodnim podružnicama inovativne farmaceutske industrije u Republici Hrvatskoj pokazalo je znatnu ovisnost njihovog poslovanja 0 strateškim usmjerenjima matičnih poduzeća. Rezultati su pokazali kako je svega nekolicina poduzeća, koja su ujedno i prisutna u Republici Hrvatskoj najduži niz godina, razvila sposobnosti posebnog skladištenja ili distribucije, dok većina njih djeluje na način zastupanja matičnog poduzeća i provođenje njegovih interesa. U navođenju ključnih inicijativa poduzetih od strana međunarodnih podružnica, najznačajnije su bile one javnozdravstvenog i marketinškog karaktera, koje ne zadiru duboko u samu strategiju poslovanja međunarodne podružnice. Većina njih definirale su se kao implementatori, u manjoj mjeri kontributori, te većinski kao minijaturne replike matičnog poduzeća. Uz to, značajan broj podružnica, uz zaposlenike hrvatskog državljanstva, na poziciju menadžmenta međunarodne podružnice postavlja ekspatrijata iz matične ili neke druge inozemne zemlje. Ideje za daljnja istraživanja ogledaju se u uključivanju i ostalih inozemnih farmaceutskih poduzeća u Republici Hrvatskoj, a koje nisu inovativnog karaktera, poradi boljeg uvida u poslovanje međunarodnih poduzeća generalne farmaceutske industrije na području Republike Hrvatske. Svakako bi kvaliteta rezultata bila znatno veća kada bi se u istraživanje uključio menadžment matičnog poduzeća, odnosno kada bi se primjerice provelo istraživanje u jednog globalnoj farmaceutskoj korporaciji i njenim međunarodnim podružnicama.
Podrug, N., Filipović, D., Bošnjak, M.

Autonomija međunarodnih podružnica u inovativnoj farmaceutskoj industriji u Republici Hrvatskoj 
Podrug, N., Filipović, D., Bošnjak, M.

Autonomija međunarodnih podružnica u inovativno farmaceutskoj industriji u Republici Hrvatskoj

\section{Literatura}

Ambos, B.,Asakawa, K.,Ambos, C. T. (2011) A dynamic perspective on subsidiary autonomy. Global Strategy Journal, 1 (3-4): 301-316.

Ambos, C. T., Birkinshaw, J. (2010) Headquarters' Attention and Its Effect on Subsidiary Performance. Management International Review, 50 (4): 449-469.

Astley, G.,Zajec, E.(1991) Intraorganizational Power and Organizational Design: Reconciling Rational and Coalitional Models of Organization. Organization Science, 2 (4): 399-411.

Birkinshaw, J., Hood, N., Young, S. (2005) Subsidiary entrepreneurship, internal and external competitive forces, and subsidiary performance. International Business Review, 14: 227-248.

Birkinshaw, J. (2014) Subsidiary Initiative in the Modern Multinational Corporation. Research in Global Strategic Management, 16: 201-220.

Brooke, M. Z. (1984) Centralization and autonomy: A study in organizational behavior. London: Holt, Rinehart \& Winston.

Cavanagh, A., Freeman, S., Kalfadellis, P., Cavusgil, S. T. (2017) How do subsidiaries assume autonomy? A refined application of agency theory within the subsidiary headquarters context. Global Strategy Journal, 7 (2): 172-192.

Chiao, Y. C., Ying, K. P. (2013) Network effect and subsidiary autonomy in multinational corporations: an investigation in Taiwanese subsidiaries. International Business Review, 22 (4): 652-662.

Dicken,P.(1976) The multiplant business enterprise and geographical space: some issues in the study of external control and regional development. Regional Studies, 10: 401-412.

Forsgren, M., Pahlberg, C. (1992) Subsidiary influence and autonomy in international firms. Scandinavian International Business Review, 1 (3): 41-51.

Gammelgaard,J. (2009) Issue Selling and Bargaining Power in Intrafirm Competition: The Differentiating Impact of the Subsidiary Management Composition. Competition and Change, 13 (3): 214-228.

Gammelgaard, J., McDonald, F., Stephan, A. (2012) The impact of increases in subsidiary autonomy and network relationships on performance. International Business Review, 21 (6): 1158-1172.

Harzing, A. W., Van Ruysseveldt, J. (2004) International Human Resource Management. Second Edition. London: SAGE Publications.

Inovativna farmaceutska inicijativa (2018) Inovativna farmaceutska inicijativa. Dostupno na: http://ifi. $\mathrm{hr} /[10.6 .2018$.$] .$

Jakobsen, S. E., Rusten, G. (2013) The autonomy of foreign subsidiaries. An analysis of headquarter subsidiary relations. Norsk Geografisk Tidsskrift-Norwegian Journal of Geography, 57 (1): 20-30.

Johnston, S. (2005) Headquarters and subsidiaries in Multinational Corporations: Strategies, Tasks and Coordination. Basingstoke: Palgrave Macmillan UK.

Johnston, S., Menguc, B. (2007) Subsidiary Size and the Level of Subsidiary Autonomy in Multinational Corporations: A Quadratic Model Investigation of Australian Subsidiaries. Journal of International Business Studies, 38 (5): 787-801.

Jong, G., Dut, V., Jindra, B., Marek, P. (2015) Does country context distance determine subsidiary decision-making autonomy? Theory and evidence from European transition economies. International Business Review, 24 (5): 874-889.

Kawai, N., Strange, R. (2013) Subsidiary autonomy and performance in Japanese multinationals in Europe. International Business Review, 3: 504-515.

Kovač,M. (2017) Utjecaj strateških inicijativa međunarodnih podružnica na matično poduzeće u industriji 
informacijsko-komunikacijske tehnologije. Doktorska disertacija Ekonomski fakultet Sveučilišta u Zagrebu.

Krupka, Z., Previšić, J., Škare, V. (2008) Utjecaj odnosa vlasničke i upravljačke funkcije na autonomiju podružnica u hrvatskim grupama poduzeća. U: Marketing u društvu znanja, Grbac, B., Meler, M. (ur.). Rijeka: Ekonomski fakultet Sveučilišta u Rijeci i CROMAR: 179-191.

Kutschker, M., Schmid, S. (2011) Internationales Management, Volume 7. Munich: De Gruyter Oldenbourg.

Leksell, L. (1981) Headquarter-subsidiary relationships in multinational corporations. Doktorska disertacija Stockholm School of Economics, Gotab, Stockholm, Sweden.

Loku,A., Shehu Loku, N. (2016) Multinational Corporations Development. Journal of Engineering Research and Applications, 6 (3): 74-83.

Lukač, D. (2013) Predstavništvo i podružnica od 1.7.2013. nakon ulaska RH u EU. Dostupno na: https:// www.teb.hr/novosti/2013/predstavnistvo-i-podruznica-od-172013-nakon-ulaska-rh-u-eu/ [8.6.2018.].

Malenica, N., Dobrić, B. (2014) Internacionalizacija poslovanja poduzeća. Zbornik radova Međimurskog veleučilišta u Čakovcu, 5 (1): 65-74.

Matić, B. (2016) Međunarodno poslovanje, institucije, pravila, strategije.Zagreb: Ekonomski fakultet Sveučilišta u Zagrebu.

Navaretti, B. G., Venables, A. (2006) Multinational Firms in the World Economy. Oxfordshire: Princeton University Press.

Picard, J. (1980) Organizational Structures and Integrative Devices in European Multinational Corporations. Columbia Journal of World Business, 15 (1): 30-55.

Pogorilić, S. (2015) Integracija principa kvalitete - temelj inovativne farmaceutske industrije. Dostupno na: https://www.aaz.hr/sites/default/files/Sekcija_1_Integracija_principa_kvalitete_-_temelj_poslovanja_ inovativne_farmaceutske_industrije_Pogorilic.pdf [17.6.2018.].

Puck, J., Hödl, M. K., Filatotchev, I., Wolff, H. G., Bader, B. (2016) Ownership mode, cultural distance, and the extent of parent firms' strategic control over subsidiaries in the PRC. Asia Pacific Journal of Management, 33 (4): 1075-1105.

Rahimić,Z., Podrug, N. (2013) Međunarodni menadžment. Sarajevo: Ekonomski fakultet u Sarajevu.

Rakita, B. (2006) Međunarodni biznis i menadžment. Beograd: Ekonomski fakultet Beograd.

Raziq, M. M., Borini, F. M., Perry, M. (2014) Subsidiary initiatives and subsidiary autonomy: Evidence from New Zealand and Brazil. International Entrepreneurship and Management Journal, 10 (3): 589-605.

Registar predstavništava stranih osoba u Republici Hrvatskoj (2015) Predstavništva stranih osoba u Republici Hrvatskoj. Ministarstvo gospodarstva, poduzetništva i obrta. Dostupno na: https://www.mingo.hr/ page/predstavnistva-stranih-osoba-u-republici-hrvatskoj [25.8.2018.].

Roth, K., Morrison, A.J. (1992) Implementing global strategies: Characteristics of global subsidiary mandates. Journal of International Business Studies, 23 (4): 715-735.

Schmid, S., Dzedek, L. R., Lehrer, M. (2014) From rocking the boat to wagging the dog: A literature review of subsidiary initiative research and integrative framework. Journal of International Management, 20 (2): 201-218.

Wilkins, M. (1970) The Emergence of Multinational Enterprise. Cambridge: Harvard University Press.

Zahra, S.A.(1991) Predictors and financial outcomes of corporate entrepreneurship: an exploratory study. Journal of Business Venturing, 6 (4): 259-285. 